Middle East Journal of Agriculture Research

EISSN: 2706-7955 ISSN: 2077-4605

DOI: 10.36632/mejar/2020.9.4.84
Volume : 09 | Issue : 04| Oct.-Dec. | 2020

Pages: 1079-1087

\title{
Effect of Foliar Application of Humic Acid, Yeast and Garlic Extracts on Growth, Yield and Quality in Forage Cowpea
}

\author{
Salwa A. A. Hassanen 1 , Walaa M. E. Mousa² and Fadia M. Sultan² \\ ${ }^{1}$ Central Lab. of Organic Agriculture, Agricultural Research Center, Giza, Egypt. \\ ${ }^{2}$ Forage Crops Res. Dept., Field Crops Res. Inst., ARC, Giza, Egypt.
}

Received: 20 Oct. 2020 / Accepted 15 Dec. 2020 / Publication date: 30 Dec. 2020

\begin{abstract}
A field experiment was conducted at Giza research station, Agriculture research center, Egypt through the two sequential summer seasons 2018 and 2019 to investigate the influence of foliar treatment of humic acid, yeast and garlic extracts on yield and quality of forage, seed yield and its components. Plants were sprayed with foliar application, humic acid, yeast and garlic extract with rate of $8 \mathrm{ml} \mathrm{L}^{-1}, 1$ $\mathrm{gm} \mathrm{L}^{-1}$ and $10 \mathrm{gm} \mathrm{L}^{-1}$ at $21,45,75,100,120$ days after sowing. The results indicated that, the treated plants with humic acid, garlic and yeast extracts achieved the higher values in all studied characters compared with the untreated plants. The values of fresh and dry forage yield were $(13.91,1.98,13.47$, 1.91 and 11.01, 1.53 ton $\mathrm{fed}^{-1}$ ) when apply of humic acid, garlic and yeast extracts, respectively. While the values of control treatment were 9.89 and 1.35 ton $\mathrm{fed}^{-1}$ for fresh and dry forage yield, respectively. The values of seed yield were $528.17,471.43$ and $402.03 \mathrm{~kg} \mathrm{fed}^{-1}$ for the treated plants with humic acid, garlic and yeast extracts as compared with the control treatment which recorded $324.99 \mathrm{~kg} \mathrm{fed}^{-1}$. Furthermore, the increase of $\mathrm{N}, \mathrm{P}$ and $\mathrm{K}$ contents, ash, protein, digestible crude protein and total digestible nutrients. The regulating influence of these substances may be attributed to its nutritional effects or its richness in phytohormones and phenolic components, so it may be applied as plant growth regulators. It could be suggested that increase the forage yield, quality and seed yield by foliar application of humic acid, natural of garlic and yeast extracts with easy preparation, low cost, it has no harmful side effects on humans and animal and environmentally safe.
\end{abstract}

Keywords: : Foliar application, Humic acid, Yeast Extract, Garlic extract, Forage yield, Quality, Seed yield, Cowpea

\section{Introduction}

Cowpea (Vigna unguiculata L. Walp) is one of the main valuable leguminous grain cultivated in the equatorial and semi equatorial regions of the world, existence the main source of food proteins, calories, dietary fiber, minerals and vitamins for a great part of the world's population (Phillips et al., 2003). In addition to grain, cowpea can produce good yields of fodder for ruminant feeding systems Ali et al., (2004). Cowpea straw is a balanced nutritious feed for animals and has key roles in animal nutrition throughout the drought period in West Africa (Singh et al., 2003 and Ilknur et al., 2012).

Humic acid is a trade compound composed of $44-58 \% \mathrm{C}, 42-46 \% \mathrm{O}, 6-8 \% \mathrm{H}$ and $0.5-4 \% \mathrm{~N}$, in addition to more different substances that enhance soil fecundity and raise the obtainability of nutrients through preserving it on a mineral surface (Larcher, 2003). Humic substances enhance yield and quality of many plant species, specially grains (Ulukan, 2008). Humic acid enhance plant physiological approaches by improving the obtainability of Macro and micro nutrients element in addition to improve the vitamins, aminoacids, and also auxin and cytokinin contents of the plants (Vanitha and Mohandass, 2014). Turan et al., (2011) reported that humic acid had effective effects on dry weight and the N, P, K uptake of plants. Sebastiano et al., (2005) showed that humic acid had an effective influence on plant growth, seed yield and quality, and photosynthetic assimilation of plant. The foliar treatment of humic acid leads to a transitional production of plant dry matter. El-Galad et al., (2013) detected that humic acid treatment considerably enhanced the soil available elements such as potassium, iron, manganese and Zink. Abd El-Gawad (2013) stated that the $8 \mathrm{~kg} \mathrm{fed}^{-1}$ dose of humic acid improving the protein proportion of seeds. 
Despite the progress of cultivation and production of cowpea crop in Egypt, its cultivation still suffer from many problems that led to a decrease in seed yield per unit area, so it has become necessary to find means various modern methods to increase production, and one of the most important of these is the development of plant nutrition and fertilization with organic materials that are safe in the environment cheap and economically viable. Therefore, this study came to the use one of biofertilizer, which is bread yeast extract which has proven its effectiveness on many crops by improving and increasing growth and yield characteristics, and yeast is one of the eukaryotic single-cell microorganisms and reality of nuclear, they reproduce by simple division or budding (Al-Esawy, 2015) yeast cell diameter ranges from 5-10 micrometer and is devoid of chlorophyll.

Undoubtedly, they used it in the manufacture of bread without knowing what it was. The scientific name Meyen was first given in 1870 AD (Lodder, 1970). And the uses of yeast developed and entered into many industrial fields, including the production of alcohol (ethanol) as a biofuel (ElHelw and Abd El-Wahed, 2010). Bread yeast contains 16 amino acids, 13 vitamins and carbohydrates (Barnett et al., 1990). Most of them are nutrients rich in what the plant needs. It was found that yeast extract activates cell division and nuclear acid formation and proteins (Fathy and Farid, 1996). It was also found that yeast produces auxin, gibberellin and cytokinin. As is known, these plant hormones are important in the germination, growth and differentiation of plant tissues and determine the extent of its response to the surrounding environmental conditions (El-Tohamy et al., 2008).

Garlic bulb (Allium sativum L.) which belongs to the family Liliaceae, garlic extract is the sap of garlic bulb. It is characterized by holding a large amount of sulfur containing amino acids, like cysteine and methionine (Synge 1971). Furthermore, Garlic contains essential compounds such as volatile oil, sugar, proteins, fibers, minerals (potassium, phosphorus, magnesium, sodium, calcium, iron) and vitamins (Al Mayahi and Fayadh 2015 and Haciseferogullari et al., 2005). The garlic extract has played several roles as a result of its hormonal (auxin-like) nature, which has a key function in lateral expansion and prolongation of cells. Regarding garlic acid influence, Helmy (1992) recorded that treatment of fresh garlic clove extract solution either in ethanol or tap water to summer squash cv. Eskandarani plants at $250 \mathrm{mg} \mathrm{DW} /$ plant lead to the preferable effects on the increment of the flowers number. Ahmed et al., (2005) cleared that a higher increment in the number of pods of pea was recorded with postinoculation application with garlic extract at $10 \mathrm{~g} / \mathrm{l}$. It has been supposed that the effective influence of garlic extract in improving crop growth and yield may be attributed to the existence of nutritional substances like minerals, enzymes, phenols, essential oils, vitamins, sulfur substances (Pandya et al., 2011), however, little is known about its content of plant hormones. The present work was carried to evaluate the influence of humic acid, yeast and garlic extracts in forage yield, quality, seed yield and yield components of forage cowpea.

\section{Materials and Methods}

A field trial was achieved at Giza Agricultural Research station, ARC, Egypt, during the two sequential summer seasons 2018 and 2019 to investigate the influence foliar treatment of humic acid, yeast and garlic (Allium Sativum) extracts on forage yield and quality, seed yield and their components on forage cowpea.

The experiments were laid-out in randomized complete block design with four replications and each experimental unit was $2 \mathrm{~m} \times 3 \mathrm{~m}$ occupying an area of $6 \mathrm{~m}^{2}$.

Mechanical and chemical properties were analyzed of the experimental soil at Giza Agric. Res. Station, according to Piper (1950) and Page et al., (1982); soil texture class was clay loam, pH 7.8 and 7.6, organic matter 0.85 and $0.82 \%$, and EC 1.83 and $1.79 \mathrm{dsm}^{-1}$ in the first and second seasons, respectively.

Entire recommended farming procedures have been used; $150 \mathrm{~kg} \mathrm{fed}^{-1}$ super phosphate $(15.5 \%$ $\left.\mathrm{P}_{2} \mathrm{O}_{5}\right)$ was applied before sowing; $45 \mathrm{~kg} \mathrm{fed}^{-1}$ of urea $(46 \% \mathrm{~N})$ and $100 \mathrm{~kg} \mathrm{fed}^{-1}$ potassium sulphate $(48 \%$ $\mathrm{k}_{2} \mathrm{O}$ ) were applied before live irrigation.

Humic acid analysis was performed for the purpose of estimating carbon, nitrogen, phosphorous, potassium, organic carbon and organic nutrients according to Jackson (1967). Sulfur was estimated by using the barium chloranilate procedure (Beaton, 1968). Fe, Mn and $\mathrm{Zn}$ were estimated by using atomic absorption (GBC 932 model), as described by Cottenie et al., (1961). Macro-micronutrients content in humic acid is recorded in Table (1). 
Table 1: Available macro-micronutrients content in humic acid.

\begin{tabular}{ccccccccccc}
\hline $\begin{array}{c}\mathbf{N} \\
\mathbf{\%}\end{array}$ & $\begin{array}{c}\mathbf{P} \\
\mathbf{\%}\end{array}$ & $\begin{array}{c}\mathbf{K} \\
\mathbf{\%}\end{array}$ & $\begin{array}{c}\mathbf{S} \\
\mathbf{\%}\end{array}$ & $\begin{array}{c}\mathbf{F e} \\
\mathbf{m g} / \mathbf{k g}^{-1}\end{array}$ & $\begin{array}{c}\mathbf{M n} \\
\mathbf{m g} . \mathbf{k g}^{-1}\end{array}$ & $\begin{array}{c}\mathbf{Z n} \\
\mathbf{m g} . \mathbf{k g}^{-1}\end{array}$ & $\begin{array}{c}\mathbf{C} \\
\mathbf{\%}\end{array}$ & $\begin{array}{c}\mathbf{C} / \mathbf{N} \\
\mathbf{r a t i o}\end{array}$ & $\begin{array}{c}\mathbf{O} . \mathbf{M} \\
\mathbf{\%}\end{array}$ & $\begin{array}{c}\mathbf{E C} \\
\left(\mathbf{d S m}^{-1}\right)\end{array}$ \\
\hline 1.79 & 0.45 & 3.71 & 3.88 & 378 & 221 & 23.25 & 43.85 & 24.50 & 61.74 & 1.62 \\
\hline
\end{tabular}

Yeast extract has been prepared by dissolving the specified weight of dry yeast in a liter of warm water, adding to it the same weight of sugar 1:1 and leaving it for 12 hours for the yeast to grow and multiply then the process of spraying until wet in the early morning.

Garlic bulbs were weighed and ground separately at the rates of $10 \mathrm{~g} / 1$ and then steeped into two teaspoonfuls vegetable oil. Each garlic and vegetable oil infusion was mixed with detergent soap and latter dissolved in a liter of water. Mixture was first stirred and latter filtered then diluted in 10 liters of water and treated as foliar spray on growing cowpea.

\section{The following treatments were applied:}

1- Untreated (Control, Mineral fertilizers in recommended doses).

2- Foliar treatment of humic acid at rate of $8 \mathrm{~m} \mathrm{~L}^{-1}$.

3- Foliar treatment of yeast extract at rate of $1 \mathrm{~g} \mathrm{~L}^{-1}$.

4- Foliar treatment of garlic extract at rate of $10 \mathrm{~g} \mathrm{~L}^{-1}$.

Foliar application of humic acid, yeast and garlic extracts after 21, 45, 75, 100 and 120 days from sowing, respectively.

One cutting was taken after 60 days from sowing then plants were left for flowering and seed production. To measure the plant growth characters, a sample of 10 plants from each plot were randomly taken.

\section{The following characters were studied Forage yield and its components}

Plant height $(\mathrm{cm})$, number of branches, number of leaves plant ${ }^{-1}$, fresh forage yield (ton $\mathrm{fed}^{-1}$ ), dry forage yield $\left(\right.$ ton fed $^{-1}$ ) and dry matter $\%$.

Seed yield and its components: pod length $(\mathrm{cm})$, number of seeds pod $^{-1}$, number of pods plant ${ }^{-1}$, seed weight plant ${ }^{-1}(\mathrm{~g}), 100$ seed weight $(\mathrm{g})$, seed yield $\left(\mathrm{kg} \mathrm{fed}^{-1}\right)$, and strew yield $\left(\mathrm{kg} \mathrm{fed}^{-1}\right)$.

Relative yield: - Was calculated according to Barakat et al., (2002) as follows:-

$$
\text { Relative yield }=\frac{\text { Fresh or dry forage or seed yield at treatment }}{\text { Fresh or dry forage or seed yield at control }} \times 100
$$

\section{Forage quality}

Plant samples for the first cut were used to determine crude fiber (CF \%) and ash percentage (Ash \%) according to A.O.A.C. (2000). Nitrogen was estimared by micro keldahl as described by Jackson (1967). Phosphorus was estimated spectrophotometrically using ammonium molybdate/stannous chloride procedure as described by Chapman and Pratt (1961). Potassium was estimated by flame photometer as described by Page et al., (1982). Raw protein content was determined using conversion of nitrogen percentage to protein (Kang et al., 2012). Protein \% calculated by the equation= N\% X Conversion factor (6.25).

Organic matter (OM \%) were estimated by using the following equation:

$\mathrm{OM} \%=100-($ Ash \%). Digestible crude protein (DCP) was calculated according to Bredon et al., (1963).

-Total digestible nutrients (TDN); was determined as described by Adams et al., (1964), using the following equation where:

$\mathrm{TDN}=74.43+0.35 \mathrm{CP}-0.73 \mathrm{CF}$

-Digestible energy $(\mathrm{DE})=\mathrm{k}$ cal / g dry matter; was calculated according to Heaney and Pigden (1963).

Where: $\mathrm{DE}=0.546+0.055 \mathrm{TDN}$. 


\section{Statistical analysis}

The collected results were statistically analyzed following the methods summarized by Steel et al., (1980) using the computer program PLABSTAT (Utz, H. F., 2004). Differences among means were tested by L.S.D at 0.05 level of significance. Bartlett's test was achieved the test of similarity of error variance. The test show insignificant differences for entire assessed features, so, the two season's data were combined.

\section{Results and Discussion}

\section{Growth characters and forage yield}

Mean values of forage yield and related characters for forage cowpea as affected by humic acid, yeast and garlic extracts from the combined analysis across seasons are presented in Table (2). Analysis of variance showed significant differences among all treatments as compared with control treatment in all traits, but it was not significant differences between humic acids and garlic extract in plant height, number of leaves plant ${ }^{-1}$. The results in Table (2) showed that using humic acid was superior in plant height, number of branches and number of leaves plant ${ }^{-1}$, recording the values $118.07 \mathrm{~cm}, 6.67$ and 37.73 , respectively. Followed by garlic extract which recorded $114.50 \mathrm{~cm}, 6.00$ and 37.47 for the same traits, respectively.

Table 2: Mean values of fodder yield and its characters for forage cowpea (combination of two seasons 2018 and 2019) as affected by humic acid, yeast and garlic extracts.

\begin{tabular}{|c|c|c|c|c|c|c|c|}
\hline Treatments & $\begin{array}{c}\text { Plant } \\
\text { height } \\
\text { (cm) }\end{array}$ & $\begin{array}{c}\text { Number } \\
\text { of } \\
\text { branches }\end{array}$ & $\begin{array}{c}\text { Number } \\
\text { of leaves } \\
\text { plant }^{-1}\end{array}$ & $\begin{array}{c}\text { Fresh } \\
\text { forage } \\
\text { yield } \\
\left.\text { (ton fed } \text { fed }^{-1}\right)\end{array}$ & $\begin{array}{c}* \text { Relative } \\
\text { yield } \\
(\%)\end{array}$ & $\begin{array}{c}\text { Dry } \\
\text { forage } \\
\text { yield } \\
\text { (ton fed }^{-1} \text { ) }\end{array}$ & $\begin{array}{c}* \text { Relative } \\
\text { yield } \\
(\%)\end{array}$ \\
\hline Control & 93.39 & 4.33 & 25.83 & 9.89 & 100.00 & 1.35 & 100.00 \\
\hline Humic acid & 118.07 & 6.67 & 37.73 & 13.91 & 140.65 & 1.98 & 146.67 \\
\hline Yeast extract & 106.77 & 5.33 & 33.60 & 11.01 & 111.32 & 1.53 & 113.33 \\
\hline Garlic extract & 114.50 & 6.00 & 37.47 & 13.47 & 136.20 & 1.91 & 141.48 \\
\hline Mean & 108.18 & 5.58 & 33.66 & 12.07 & & 1.69 & \\
\hline LSD at 0.05 & 6.63 & 0.62 & 3.18 & 1.10 & & 0.15 & \\
\hline
\end{tabular}

*The relative fresh and dry fodder yields were calculated for treatments as a percentage from the control.

While the lowest values $106.77 \mathrm{~cm}, 5.33,33.60$ for the same characters, respectively, were recorded with yeast extract treatment.

Means of forage cowpea as affected by humic acid, yeast and garlic extracts for fresh and dry fodder yields (ton $\mathrm{fed}^{-1}$ ), and their relative yield in comparison to control during the both successive seasons are shown in Table (2).

Data presented in Table (2) cleared significant variations between all treatments as compared with control treatment in fresh and dry fodder yields. While, it was not significant differences between humic acids and garlic extract. Foliar application of humic acid produced the highest values of fresh and dry forage yields (13.91 and 1.98 ton fed $^{-1}$ ), respectively and transcended the control treatment by (40.65 and 46.67\%), respectively. Followed by foliar application of garlic extract which recorded (13.47 and 1.91 ton $^{\text {fed }}{ }^{-1}$ ) for fresh and dry forage yields, respectively. and exceeded the control treatment by (36.20 and 41.48\%), Meanwhile, Foliar application of yeast extract appeared the lowest fresh and dry fodder yields (11.01 and 1.53 ton fed $^{-1}$ ), respectively and it was transcended than the control treatment by (11.32 and 13.33\%), respectively. Sebastiano et al., (2005) showed that humic acid had an effective influence on plant growth, seed yield and quality, and photosynthetic assimilation of plant. The foliar treatment of humic acid leads to a transitional production of plant dry matter. On the other hand garlic extract regulation in vegetative growth involving leaf, stem and branch and elongation in plants stimulated by garlic extract treatment may be related with the necessary components exist in garlic. Nevertheless, this improvement in the plant growth may also as a result of auxins and other plant hormones existence in the garlic extract. It is well known that auxins regulate cell extension, stem growth, plant height, leaves number and root initiation in addition t0 induce plant development (Colla et al., 2014 and Elzaawely et al., 2018). Gibberellins also stimulate cell and stem prolongation, cell division and leaf extension (Hedden and Sponsel, 2015). This is also due to the role of yeast extract in 
increasing the efficiency of the vital processes that occur inside the plant, as the yeast extract contains a group of amino acids that act as building units in the reactions producing amino acids inside the plant, as well as containing nitrogen and some mineral elements that work on activate growth and actively contribute to building chlorophyll in leaves. In addition, yeast extract is a natural source of cytokinins that play a major role in cell division and proliferation and increase their growth rates, which affects by increasing branching and root formation, and this means that the plant can express itself at the best levels with the nutritional richness that this extract contains (Branett et al., 1990 and Day, 1990).

\section{Forage quality}

Mean values of forage quality characters as affected by humic acid, yeast and garlic extracts from the combined analysis across seasons are presented in Tables ( 3 and 4). Analysis of variance showed significant differences among all treatments as compared with control treatment in all traits, but it was not significant differences between humic acid and garlic extract. The results in Tables ( 3 and 4$)$ showed that using humic acid was superior in crude protein $(\mathrm{CP} \%)$, digestible crude protein $(\mathrm{DCP} \%), \mathrm{Ash} \%$, dry matter $\%$, total digestible nutrients (TDN\%), digestible energy (DE\%), N\%, $\mathrm{P} \%$ and $\mathrm{K} \%$ recording the values $21.01 \%, 16.61 \%, 14.19 \%, 14.23 \%, 65.58 \%, 4.15 \%, 3.36 \%, 0.38 \%$ and $1.48 \%$ respectively. Followed by garlic extract which recorded $20.86 \%, 16.47 \%, 14.07 \%, 14.17 \%, 65.32 \%, 4.14 \%, 3.34 \%$, $0.35 \%$ and $1.44 \%$ for the same traits, respectively. The current data is a coincidence with Shaban et al., (2012) found that foliar treatment of humic acid lead to a significant enhance in protein content. While the lowest values $19.93 \%, 15.57 \%, 12.60 \%, 13.87 \%, 64.31 \%, 4.08 \%, 3.19 \%, 0.33 \%$ and $1.31 \%$ for the same characters, respectively, were recorded with yeast extract treatment.

Means of crude fiber (CF \%) and organic matter (OM \%) gave the highest values by using yeast extract, it was recorded $23.42 \%$ and $87.40 \%$, respectively. While the lowest values were recorded by using humic acid, it was recorded $22.19 \%$ and $85.81 \%$, respectively.

Similar data were gained by Gad et al., (2012), they demonstrating that the foliar treatment of humic acid caused the greatest rates of N, P and $\mathrm{K}(\%)$ concentration in plant in comparison to untreated plants. Hussien and Hassan (2011) showed that the foliar treatment of humic acid improved the uptake of phosphorus and potassium. Moreover, inorganic nutrient elements such as N, P and $\mathrm{K}$ were excessed in snap bean leaves and pods after garlic extract treatment. This may be due to the great amounts of minerals and important nutrients in the garlic extract (Shakir and Al-Rawi 2017)

This may be due to promoting the growth and enhancement of forage cowpea plants and keeping for the high yield in terms of quantity and quality. Furthermore the bioactive substances exist in humic acid, garlic, and yeast extracts, their plant hormones act as a plant growth stimulator.

Table 3: Forage quality of forage cowpea as affected by humic acid, yeast and garlic extracts (combined across 2018 and 2019 seasons).

\begin{tabular}{lcccccc}
\hline Treatments & Dry matter \% & Ash \% & CF \% & OM\% & TDN\% & DE\% \\
\hline Control & 13.61 & 10.77 & 24.61 & 89.23 & 63.05 & 4.01 \\
Humic acid & 14.23 & 14.19 & 22.19 & 85.81 & 65.58 & 4.15 \\
Yeast extract & 13.87 & 12.60 & 23.42 & 87.40 & 64.31 & 4.08 \\
Garlic extract & 14.17 & 14.07 & 22.48 & 85.93 & 65.32 & 4.14 \\
Mean & 13.97 & 12.91 & 23.18 & 87.09 & 64.57 & 4.10 \\
LSD at 0.05 & 0.15 & 1.15 & 0.91 & 1.36 & 0.93 & 0.05 \\
\hline
\end{tabular}

CF: Crude Fiber, OM: Organic matter, TDN: Total digestible nutrients, DE: Digestible energy

Table 4: Forage quality of forage cowpea as affected by humic acid, yeast and garlic extracts (combined across 2018 and 2019 seasons).

\begin{tabular}{lccccc}
\hline Treatments & $\mathbf{N \%}$ & $\mathbf{P \%}$ & $\mathbf{K \%}$ & $\mathbf{C P} \%$ & DCP \% \\
\hline Control & 3.01 & 0.30 & 1.22 & 18.82 & 14.51 \\
Humic acid & 3.36 & 0.38 & 1.48 & 21.01 & 16.61 \\
Yeast extract & 3.19 & 0.33 & 1.31 & 19.93 & 15.57 \\
Garlic extract & 3.34 & 0.35 & 1.44 & 20.86 & 16.47 \\
Mean & 3.23 & 0.34 & 1.36 & 20.15 & 15.79 \\
LSD at 0.05 & 0.11 & 0.03 & 0.07 & 0.89 & 0.76 \\
\hline
\end{tabular}




\section{Seed yield and its components}

Data in Table (5) clear that pod length $(\mathrm{cm})$, number of pods plant ${ }^{-1}$, seed weight plant ${ }^{-1}(\mathrm{~g})$, number of seeds pod $^{-1}$ and 100- seed weight $(\mathrm{g})$ were significant differences among treatments and control. But it was not significant differences between humic acid and garlic extract in all above mention traits. The highest values were found by using humic acid, it was recorded $15.57 \mathrm{~cm}, 21.73,15.25 \mathrm{~g}$, 15.73 and 13.19 for pod length, number of pods plant ${ }^{-1}$ seed weight plant $^{-1}(\mathrm{~g})$, number of seeds pod ${ }^{-1}$ and 100- seed weight (g). It was exceed than control by $43.4 \%, 33.9 \%, 10.2 \%, 38.8 \%$ and $23.6 \%$, respectively. Followed by garlic extract which recorded $14.43 \mathrm{~cm}, 21.13,14.99 \mathrm{~g}, 14.03$ and 13.08, respectively for the same characters by exceeding values than control $32.9 \%, 30.2 \%, 8.6 \%, 23.8 \%$ and $22.6 \%$. Meanwhile, the lowest values were recorded by using yeast extract it was gave $13.93 \mathrm{~cm}, 16.47$, $14.31 \mathrm{~g}, 12.03$ and 11.78 for pod length, number of pods plant ${ }^{-1}$ seed weight plant ${ }^{-1}$, number of seeds pod $^{-1}$ and 100- seed weight, respectively.

Table 5: Mean values of seed yield related characters for forage cowpea as affected by humic acid, yeast and garlic extracts (combined across 2018 and 2019 seasons).

\begin{tabular}{lccccc}
\hline Treatments & $\begin{array}{c}\text { Pod } \\
\text { length } \\
\text { (cm) }\end{array}$ & $\begin{array}{c}\text { Number of } \\
\text { pods plant }^{-1}\end{array}$ & $\begin{array}{c}\text { Seed weight } \\
\text { plant }^{-1} \mathbf{( g )}\end{array}$ & $\begin{array}{c}\text { Number of } \\
\text { seeds pod }^{-1}\end{array}$ & $\begin{array}{c}\text { 100-seed } \\
\text { weight (g) }^{(\mathbf{g})}\end{array}$ \\
\hline Control & 10.86 & 16.23 & 13.80 & 11.33 & 10.67 \\
Humic acid & 15.57 & 21.73 & 15.25 & 15.73 & 13.19 \\
Yeast extract & 13.93 & 16.47 & 14.31 & 12.03 & 11.78 \\
Garlic extract & 14.43 & 21.13 & 14.99 & 14.03 & 13.08 \\
Mean & 13.70 & 18.89 & 14.59 & 13.28 & 12.18 \\
LSD at 0.05 & 1.16 & 4.26 & 0.49 & 1.87 & 1.04 \\
\hline
\end{tabular}

Means of forage cowpea as affected by humic acid, yeast and garlic extract for seed yield $\left(\mathrm{kg} \mathrm{fed}^{-1}\right)$, Strew yield (kg $\left.\mathrm{fed}^{-1}\right)$, Biological yield $\left(\mathrm{kg} \mathrm{fed}^{-1}\right)$, Harvest Index $(\%)$ and relative yield in comparison with control through the two seasons are shown in Table (6).

Data in Table (6) cleared significant variations between all treatments as compared with control treatment in seed yield, strew yield, biological yield, harvest index and relative yield. While, it was not significant differences between humic acid and garlic extract. Foliar application of humic acid produced the highest values of seed yield $\left(528.17 \mathrm{~kg} \mathrm{fed}^{-1}\right)$ and exceeded the control treatment by $(62.52 \%)$, highest strew yield $\left(289.57 \mathrm{~kg} \mathrm{fed}^{-1}\right)$, biological yield $\left(817.74 \mathrm{~kg} \mathrm{fed}^{-1}\right)$ and harvest index $(64.59 \%)$, respectively. Followed by foliar application of garlic extract which recorded $\left(471.43 \mathrm{~kg} \mathrm{fed}^{-1}\right)$ and exceeded the control treatment by $(45.06 \%)$, strew yield $\left(277.77 \mathrm{~kg} \mathrm{fed}^{-1}\right)$, biological yield $(749.20 \mathrm{~kg}$ $\left.\mathrm{fed}^{-1}\right)$ and harvest index $(62.92 \%)$, respectively Meanwhile, Foliar application of yeast extract produced the lowest seed yield $\left(402.03 \mathrm{~kg} \mathrm{fed}^{-1}\right)$ and it was exceeded significantly than the control treatment by (23.71\%), strew yield $\left(226.27 \mathrm{~kg} \mathrm{fed}^{-1}\right)$, biological yield $\left(628.30 \mathrm{~kg} \mathrm{fed}^{-1}\right)$ and harvest index $(63.99 \%)$, respectively. These results are in agreement with Branett et al., (1990) and Day, (1990).

Table 6: Mean values of seed yield and its characters for forage cowpea as affected by humic acid, yeast and garlic extracts (combined across 2018 and 2019 seasons).

\begin{tabular}{|c|c|c|c|c|c|}
\hline Treatments & $\begin{array}{l}\text { Seed yield } \\
\left(\mathrm{kg} \mathrm{fed}^{-1}\right)\end{array}$ & $\begin{array}{c}\text { * Relative yield } \\
(\%)\end{array}$ & $\begin{array}{c}\text { Strew yield } \\
\left.\text { (kg fed }^{-1}\right)\end{array}$ & $\begin{array}{c}\text { Biological yield } \\
\left(\mathrm{kg} \mathrm{fed}^{-1}\right)\end{array}$ & $\begin{array}{c}\text { Harvest Index } \\
(\%)\end{array}$ \\
\hline Control & 324.99 & 100.00 & 184.72 & 509.71 & 63.76 \\
\hline Humic acid & 528.17 & 162.52 & 289.57 & 817.74 & 64.59 \\
\hline Yeast extract & 402.03 & 123.71 & 226.27 & 628.30 & 63.99 \\
\hline Garlic extract & 471.43 & 145.06 & 277.77 & 749.20 & 62.92 \\
\hline Mean & 431.66 & & 244.58 & 676.24 & \\
\hline LSD at 0.05 & 63.60 & & 39.06 & 78.15 & \\
\hline
\end{tabular}

*The relative seed yield was calculated for treatments as a percentage from the control.

In the current trial in two growing seasons, garlic extract improved the yield components of forage cowpea involving pod length and number, which concomitant with the noticed enhance in pod yield. The improvement in pod yield may be attribute to the raise in chlorophyll content in the forage cowpea leaves lead to the possible improve in the rate of photosynthesis and accumulation of dry materials, hence pod yield. Moreover, gibberellins and cytokinins have been recorded to enhance pod 
set and afterwards pod number that was related with an improve in seed yield in several plants such as soybean (Dyer et al., 1987) and snap bean (Emongor 2015; Elzaawely et al., 2017 and Elzaawely et al., 2018). Therefore, it can be suggested that increasing of seed yield fed ${ }^{-1}$ as a result of foliar applications is mainly caused by the raises in number of branches, number of pods plant ${ }^{-1}$ and 100 seed weight (gm). The improvement in yield and its components may be attributed to the influence of all foliar applications on improving criteria for forage cowpea.

\section{Conclusion}

In this study, humic acid, garlic and yeast extracts foliar treatment cleared a regulate influence on forage cowpea plants causing by enhanced growth and physiological functions involving photosynthetic capacity and endogenous plant hormones that can ensure raised production of forage cowpea with high quality. Humic acid, garlic and yeast extracts could be desirable in agricultural production cussed by their different properties involving easy preparation, low cost and environmentally secure.

\section{References}

Abd El-Gawad, M.A.A., 2013. Effect of humic acid application as well as bio and mineral phosphorus fertilization on growth, green pods, dry seed yield and quality of peas (Pisum stivum L.) under the newly reclaimed soil conditions. Egypt. J. Appl. Sci. 28 (27): 338-360.

Adams, R.S., J.H. Moore, E.M. Kesler and G.Z. Stevens, 1964. New relationships for estimating TDN content of forages from chemical composition. J.D. Dairy Sci., 47: 1461. Agric., (27): 436-441.

Ahmed S., J. Iqbal, and I. Attauddin, 2005. Time of application effect of phytobiocides on powdery mildew and yield in pea. Sarhad J. Agric. 21:729-731.

Ali, Y., Z. Aslam, F. Hussain and A. Shakur, 2004. Genotype and environmental interaction in cowpea (Vigna unguiculata L.) for yield and disease resistance. Int. J. Environ. Sci. and Tech., 1:119.

Al-Esawy, Y.G.A., 2015. Effect of foliar feeding with bread yeast extract (Saccharomyces cereviciae) on yield components and protein percentage of three varieties of beans. Egyptian J. for Applied Sci., 29 (1): 41-56.

Al Mayahi M.A. and M.H. Fayadh, 2015. The effects of garlic extract, its application methods and their interaction on growth and yield of potato, Solanum tuberosum (L.) Cv. Latonia. AAB Bioflux. , 7(1):59-69

A.O.A.C., 2000. Official Methods of Analysis of the Association of Official Analytical Agricultural Chemists, $17^{\text {th }}$ Ed. Published by A.O.A.C., Washington USA.

Barnett, J.A., R.W. Payne and D. Yarrow, 1990. Yeasts characterization and identification. Cambridge, camb. CBZBR, 999.

Barakat, A.H., S.M. Abdel-Aal and I.M. Ahmed, 2002. Comparative study on the effect of soil and foliar application of nitrogen fertilization on growth and productivity of Egyptian clover (Trifolium Alexandrinum, L). Minufiya. J. of Agric. Research., 27(3): 499-509.

Beaton, J.D., G.R. Burns and J. Platou, 1968. Determination of sulfur in soils and plant material. The Sulfur Institute, Washington, D.C.

Bredon, R.M., K.W. Harker and B. Marshall, 1963. The nutritive value of grasses grown in Uganda when feed to zebu cattle. 1- The relation between the percentage of crude protein and other nutrients. J. Agric. Sci., 61: 101-104.

Chapman, H.D. and P.F. Pratt, 1961. Methods of analysis for soils, "Plants and Water". Agric. Publ. Univ., of California, Reverside.

Colla, G., Y. Rouphael, R. Canaguier, E. Svecova and M. Cardarelli, 2014. Biostimulant action of a plant-derived protein hydrolysate produced through enzymatic hydrolysis. Front Plant Sci., $5: 1-5$.

Cottenie, A., M. Verloo, G. Velghe and R. Cameriynck, 1961. "Chemical Analysis of Plant and Soil" Laboratory of Analytical and Agrochemistry, State Univ., Ghent, Belgium.

Day, A., 1990. Organic food, a guide from the ministry of agriculture fisheries and food. Washington state Department of Agriculture organic food programs website at http://agr. wa.gov/frash /organie/of p.htm. 
Dyer, D.J., D.R. Carlson, C.D. Cotterman, J.A. Sikorski, and S.L. Ditson, 1987. Soybean pod set enhancement with synthetic cytokinin analogs. Plant Physiol., 84:240-243.

Gad, S.H., A.M. Ahmed and Y.M. Moustafa, 2012. Effect of foliar application with two antioxidants and humic acid on growth, yield and yield component of pea (Pisum sativum L.). J. Hort. Sci. and Ornamental Plants, 4(3): 318-328.

El-Galad, M.A., D.A. Sayed and R.M. El-Shal, 2013. Effect of humic acid and compost applied alone or in combination with sulphur on soil fertility and faba bean productivity under saline soil conditions. J. Soil Sci. and Agric. Eng., Mansoura Univ., 4 (10): 1139-1157.

El-Helw, N.G. and H.E. Abd El-Wahed, 2010. Production of ethanol from a mixture of sugars is mediated by a mixture of yeast. Engineering and Technology Journal, 28 (22): 11-21.

El-Tohamy, W.A., H.M. El-Abary and N.H. M. El-Greadly, 2008. Studies of the effect of puterscine, yeast and vitamin $\mathrm{C}$ on growth, yield and physiological responses of eggplant (Solanum Melongena L.) under Sandy soil conditions. Australian J. of Basic and APP Sci., 2(2): 296-300.

Elzaawely, A.A., M.E. Ahmed, H.F. Maswada and T.D. Xuan, 2017. Enhancing growth, yield, biochemical, and hormonal contents of snap bean (Phaseolus vulgaris L.) sprayed with moringa leaf extract. Arch. Agron. Soil Sci., 63:687-699.

Elzaawely, A.A., M.E. Ahmed, H.F. Maswada, A.A. Al-Araby and T.D. Xuan, 2018. Growth traits, physiological parameters and hormonal status of snap bean (Phaseolus vulgaris L.) sprayed with garlic cloves extract. Archives of Agronomy and Soil Science, 64 (8): 1068-1082.

Emongor, V.E., 2015. Effects of moringa (Moringa oleifera) leaf extract on growth, yield and yield components of snap beans (Phaseolus vulgaris). Br. J. Appl. Sci. Technol., 6:114-122.

Fathy, S.L. and S. Farid, 1996.The possibility of using vitamin B and yeast to delay senescence and improve growth and yield of common beans (Phaseolus Vulgaris L.) J. Agric. Sci. Mansoura Univ., 21(4): 1415-1523.

Haciseferogullari, H., M. Ozcan, F. Demir, and S. Çalışır, 2005. Some nutritional and technological properties of garlic (Allium sativum L.). J. Food Eng., 68:463-469.

Heaney, D.P. and W.J. Pigden, 1963. Interrelationships and conversion factors between expressions of the ddigestible energy value of forages. Journal of Animal Science, 22 (4): 956-960.

Hedden, P. and V. Sponsel, 2015. A century of gibberellin research. J. Plant Growth Regul. 34:740760.

Helmy E.M.S., 1992. Response to summer squash application methods of fresh garlic extracted by different solvents. Alex. J. Agric. Res., 37:125-142.

Hussein, Kh. and A.F. Hassan, 2011. Effect of different levels of humic acids on the nutrient content, plant growth and soil properties under conditions of salinity. Soil and Water Res., 6 (1): 21-29.

Ilknur, A.Y.A.N., M.U.T. Hanife, B.A.S.A. Ugur, A.C.A.R. Zeki and A.S.C.I. Ozlem Onal, 2012. Forage potential of cowpea (Vigna unguiculata L. Walp). Turkish Journal of Field Crops, 17(2):135-138.

Jackson, M.L., 1967. "Soil Chemical Analysis" Constable and Co. LTP., London, England.

Kang, S.M., A.L. Khan, M. Hamayun, Z.K. Shinwari, Y.H. Kim, G.J. Joo and I.J. Lee, 2012. Acinetobacter calcoaceticus ameliorated plant growth and influenced gibberellins and functional biochemicals. Pak. J. Bot., 44 (1): 365-372.

Larcher, W., 2003. Physiologial plant ecology: Ecophysiology and stress physiology of functional groups, $4^{\text {th }}$. Ed., Springer, New York.

Lodder, J., 1970. The yeast .2 nd, North Holland Publishing Company. Nether lands.

Page, A.L., R.H. Miller and D.R. Keeney, 1982. Methods of soil analysis. II Chemical and microbiological properties $2^{\text {nd }}$ Ed. Madison, Wisconsim, U.S.A.

Pandya, K., B. Solanki, K. Maniar, N. Gurav, and S. Bhatt, 2011. Natural herbal supplements-A study on their nutritional value and their phytochemical constituents. Int J Pharm Sci Res., 2:14801494.

Piper, C.S., 1950. Soil and plant analysis. Inter. science pubi. Inc. New York. Plant and soil, 91(3): 429432.

Phillips, R.D., K.H. McWatters, M.S. Chinnan, Y.C. Hung, L.R. Beuchat, S. Sefa-Dedeh, E. SakyiDawson, P. Ngoddy and D. Nnanyelugo, 2003. Utilization of cowpeas for human food. Field Crops Res., 82: 193-213. 
Sebastiano, D., Roberto, T. Ersilio, D. and A. Arturo, 2005. Effect of foliar application on N and humic acids on growth and yield of durum wheat. Agron. Sustain. Dev., 25 (2): 183-191.

Shaban, Kh.A., M.G. Abd El-Kader and Z.M. Khalil, 2012. Effect of soil amendments on soil fertility and sesame crop productivity under newly reclaimed soil conditions. J. of Appl. Sci. Res., 8(3): $1568-1575$.

Shakir, M.A., W. Al-Rawi, 2017. Effect of garlic and licorice root extracts on leaves mineral and hormonal content of pear transplants. Iraqi J. Agric. Sci., 48:131-143.

Singh, B. B., H. A. Ajeigbe, S. A. Tarawali, S. Fernandez-Rivera and M. Abubakar, 2003. Improving the production and utilization of cowpea as food and fodder. Field Crops Res., 84:169.

Steel, R.G., J.H. Torrie and D.A. Dickey, 1980. Principles and Procedures of Statistics: A Biometrical Approach. $2^{\text {nd }}$ Edition, McGraw-Hill Book Co., Inc., New York.

Synge R.L.M., 1971. Proteins and poisons in plant. Nature Wissen Schaftliche Rundschar 24(2):54-61

Turan, M.A, B.B. Asik, A.V. Katkat and H. Celik, 2011. The effect of soil applied humic substances to the dry weight and mineral nutrient uptake of faba bean plants under soil salinity conditions. Not. Bot. Hort. Agrobot. Cluj., 39 (1): 171-177.

Utz, H. F., 2004. PLABSTAT, a computer program for statistical analysis of plant breeding experiments. Institute of Plant Breeding, Seed Science and Population Genetics, Hohenheim Univ., Stuttgart, F.R. Germany.

Ulukan, H., 2008. Effect of soil applied humic acid at different sowing times on some yield components in wheat (Trticum spp.) hybrids. Int. J. Bot. 4(2): 164-175.

Vanitha, K. and S. Mohandass, 2014. Effect of humic acid on plant growth characters and seed yield of drip fertigated aerobic rice (Oryza sativa L.). J. The Bioscan., 9(1):45-50. 